Received 28 May 2020, Accepted 18 December 2020

Link to DOI:

10.25220/WNJ.V05.11.0009

Journal Website: www.worldnutrijournal.org

\section{The effect of vitamin D supplementation during pregnancy on the risk of having preterm birth: An evidence-based case report}

\author{
Intan Meilana, ${ }^{1}$ Diyah Eka Andayani ${ }^{1}$ \\ 1. Department of Nutrition, Faculty of Medicine, Universitas Indonesia, Dr. Cipto Mangunkusumo \\ General Hospital, Jakarta, Indonesia
}

\begin{abstract}
Introduction: Preterm birth (PTB) is a major cause of neonatal morbidity and mortality. Pregnant woman is one of the most vulnerable groups for vitamin D deficiency, that increase the risk of PTB. Vitamin $D$ has the role of immunomodulator, anti-inflammatory, and transcription of genes involved in placental function. Research results on the correlation between vitamin $D$ supplementation and PTB risk are still inconsistent.

Objectives: To observe the effect of oral vitamin $D$ supplementation during pregnancy on the risk of PTB

Methods: Advanced search for relevant literatures in PubMed, Cochrane, and Willey was conducted. After assessing the relevancy and eligibility, articles were selected and critically appraised.

Results: There were three articles that relevant with the eligibility criteria and clinical questions, they were randomized controlled trial, meta-analysis and systematic review. Three studies found that oral vitamin $D$ supplementation in the form of cholecalciferol during pregnancy had a significant reduction on the risk of PTB. A systematic review found that supplementation with combination of cholecalciferol and calcium carbonate may increase the risk of PTB. The different dosages, frequencies, and time of initiation limit the generalizations for efficacy and safety doses.

Conclusions: Oral cholecalciferol supplementation during pregnancy reduces the risk of PTB. While supplementation with combination of cholecalciferol and calcium carbonate requires consideration. Research on the effect of oral vitamin D supplementation during pregnancy on the risk of PTB is still limited and need for more studies. Recommendation for vitamin D consumption based on the RDA needs to be fulfilled in pregnant women.

Keywords pregnancy, vitamin D, vitamin D3, cholecalciferol, preterm birth, preterm labor
\end{abstract}

\section{Introduction}

Preterm birth (PTB) is defined as birth that occurs between 20 to 37 weeks of pregnancy. The rate

\begin{tabular}{l}
\hline Corresponding author: \\
Intan Meilana \\
Department of Nutrition, Faculty of Medicine, \\
Universitas Indonesia-Dr. Ciptomangunkusumo \\
Hospital \\
Jl. Salemba Raya No.6, Central Jakarta, Indonesia \\
Email: ntnmeilana@gmail.com \\
\hline
\end{tabular}

ranges from $5 \%$ to $18 \%$ of babies born. Every year an estimated 15 million babies are born prematurely, increasing in most countries and becoming a global issues. ${ }^{1-3}$ In 2017, 5.4 million children under 5 years old died and PTB complications are the leading cause of their deaths. ${ }^{1,4}$ According to WHO, Indonesia is the ninth country with the highest PTB rate, which is 15.5 per 100 live births. Also the fifth country with the greatest number of PTB, which is 675,700 births. $^{1}$

Preterm babies may be born with serious health problems, include motor and cognitive neurodevelopmental disabilities (cerebral palsy, 
blindness, deafness, mental retardation, and learning disabilities), chronic lung disease and gastrointestinal problems. ${ }^{2,5,6} \mathrm{PTB}$ is associated with a 3 to 4-fold higher incidence of adverse maternal outcomes including the need for blood transfusion and prolonged hospitalization, and increased frequency of cesarean births more than doubled. ${ }^{7}$

There are several common cause of PTB, inflammation and infection are highly significant risk factors. ${ }^{1,2,5}$ Vitamin D is suggested to influence physiological pathways involved in PTB, including inflammation, immunomodulation, and transcription of genes involved in placental function. ${ }^{8-10}$ Vitamin $\mathrm{D}$ has the effect of suppressing some inflammatory cytokines. Vitamin D receptors are present in immune cells, which produce antimicrobial peptides and prevent perinatal infections. ${ }^{10}$ Poor maternal nutrition at preconception and during early pregnancy also affect the risk of PTB. ${ }^{8}$ Pregnant women is one of the most vulnerable groups for vitamin D deficiency. ${ }^{11}$ Research has suggested that maternal vitamin D deficiency, or insufficiency, has related to several adverse maternal and fetal outcomes, including preterm labor (PTL) or PTB. ${ }^{6,11}$

There have been several studies that describe the relationship between vitamin $\mathrm{D}$ supplementation and PTB, however, the results were inconsistent. Mojibian M., et al., ${ }^{12}$ showed that consumption of 50,000 IU vitamin D every 2 weeks from 12 weeks of pregnancy until delivery the incidence of PTL were not significantly different. Meanwhile, Persad MD., et al., ${ }^{13}$ showed that vitamin D supplementation was associated with the prevention of PTB (RR 0.54; 95\% CI 0.42-0.68). Therefore, the aim of this study to analyze the effect of oral vitamin D supplementation during pregnancy on the risk of PTB.

\section{Clinical question}

Can vitamin D supplementation during pregnancy reduce the risk of having preterm birth?

P: Pregnant women

I: Oral vitamin D supplementation

C: Placebo or without vitamin D supplementation

$\mathrm{O}$ : Risk of preterm birth

\section{Methods}

Strategy of article searching
Advanced searching was used for this literature searching from three main databases: PubMed, Cochrane, and Willey on May 15 th 2020 (Table 1)

\section{Strategy of article selection}

\section{Eligibility Criteria}

The article was selection based on the inclusion and exclusion criteria. Inclusion criteria were: (1) Pregnant women, (2) Oral vitamin D supplementation, (3) Comparison with placebo or without vitamin D supplementation, (4) Preterm birth or preterm labor as the study outcome, (5) Systematic review of randomized controlled trial (RCT), meta-analysis or RCT (6) Publication within the last 5 years. Exclusion criteria were: (1) Not in accordance with the clinical question, (2) There is no full text available, (3) Article is not written in English.

\section{Method of Critical Appraisal}

Articles were reviewed by all authors using the critical appraisal method according to the Center of Evidence-Based Medicine for therapy studies. Critical appraisal was done on the articles, so that the validity, importance and applicability could be assessed. The level of evidence in this study was determined based on the Oxford Center for Evidence-based Medicine - Levels of Evidence.

\section{Results}

Following of the search strategy, three original articles were eligible for this evidence-based case report (Figure 1). The first study was a RCT with level of evidence of 2 , the second study was a systematic review with level of evidence of 1 , the third study was a meta-analysis with level of evidence of 1 . Characteristics of the studies are shown in Table 2. Critical appraisal was carried out in all articles, the results can be seen in Table $\mathbf{3}$ and Table 4.

\section{Discussion}

The first study by Sablok A., et al., ${ }^{11}$ that conducted a randomized controlled trial (RCT) to 180 primigravidae with singleton pregnancy at 14-20 
weeks. Participants were divided into two groups, group A formed the non-intervention group whereas group B formed the cholecalciferol supplementation group, with a dose dependent on the estimated 25OHD serum level at baseline. One of the risk of maternal complications as outcome of this study was PTL or PTB. The result of this study was $21.1 \%$ of the patients in group A had PTB compared to $8.3 \%$ in group $\mathrm{B}$, a significant decrease in incidence of PTB in the supplementation group $(p=0.02) .{ }^{11}$

The second study is a systematic review by Luz Maria D., et al., ${ }^{14}$ that included 15 RCTs involving 2833 pregnant women. One of the primary outcome of this study was to determine whether oral vitamin D supplementation alone or in combination with calcium or other vitamins and minerals can reduce the risk of PTB. This study method was based on a standard template used by Cochrane Pregnancy and Childbirth. GRADE was used to assess the quality of evidence and the strength of recommendations. As only one study was considered of high quality, sensitivity analyzes in this study was not conducted. ${ }^{14}$

Oral vitamin D supplementation in the form of cholecalciferol during pregnancy reduces the risk of PTB compared to no intervention or placebo (RR $0.36,95 \%$ CI 0.14 to $0.93 ; 3$ trials, 477 women, moderate quality). Only one reported case of nephritic syndrome in the control group in one study (RR $0.17,95 \%$ CI 0.01 to 4.06 ; 1 trial, 135 women, low quality). Due to limitations of data for maternal adverse events, no conclusions could be drawn. ${ }^{14}$

Oral supplementation with combination of vitamin D (cholecalciferol) and calcium (calcium carbonate) increased the risk of PTB compared to no treatment or placebo (RR 1.57, 95\% CI 1.02 to 2.43 ; 3 trials, 798 women, moderate quality). No trial reported on maternal adverse events in supplementation with combination of vitamin D and calcium. There were no studies included in supplementation with combination of vitamin D and calcium compared to supplementation with calcium (without vitamin D), and supplementation with combination of vitamin $\mathrm{D}$, calcium and other vitamins and minerals. ${ }^{14}$

The third study is a meta-analysis by Zhou S., et al, ${ }^{15}$ that included six RCTs and 18 observational studies. The six RCTs in this study investigated whether vitamin D supplementation during pregnancy can reduce the risk of PTB. The risk for PTB among women receiving supplement ranged from 0.06 to 1.20 , and positive and significant results were reported in one out of the six RCTs. Three RCTs had a low risk of bias, one had a moderate risk of bias, and two had a high risk of bias. $^{15}$

Vitamin D3 dosage used for the intervention groups ranged from a daily dosage of 400 IU to multiple bolus dosage of 120,000 IU. The result of meta-analysis in six RCTs involved 1687 pregnant women was $\mathrm{RR}=0.57(95 \% \mathrm{CI}: 0.36-0.91)$ and test of heterogeneity, $I^{2}=26.2 \% \quad(p=0.238)$, suggested that women who received vitamin D3 supplementation during pregnancy had a lower risk of PTB compared to women who received placebo or routine antenatal care. In the subgroup analysis of RCT, the studies with sample size $>100$, low risk of bias and single-dose supplementation of vitamin D3, could reduce the risk of PTB, but no conclusions could be drawn because the subgroups had only one or two RCTs, and the results may be misleading. RCT sensitivity analysis showed that there were two studies that significantly influence the results. The small sample size produced unstable results, therefore it was difficult to exclude the possibility that the positive association was due to chance. ${ }^{15}$

This meta-analysis tried to explain the effect of vitamin D on PTB risk. The possible protective effect of vitamin D against PTB by reducing infection and inflammation, as the major cause of PTB. Maternal serum 25-OHD and 1,25-diOHD also can inhibit inflammatory factors, such as tumor necrosis factor- $\alpha$ and interleukin 6 , while at the same time promoting anti inflammatory cytokine and cathelicidin, responding to microbial invasion through activation of toll-like receptors on monocytes and macrophages. Vitamin D may also affect placental function, given that 1,25dihydroxyvitamin D3 can reduce oxidative stress, which is associated with iatrogenic PTB. ${ }^{15}$ Limitations of intervention studies in this metaanalysis were inconsistent dosage regimen, timing of initiation and quality of design were limited the efficacy of generalization. ${ }^{15}$ 


\section{Conclusion}

All three studies, RCT, meta-analysis and systematic review, found that oral vitamin $\mathrm{D}$ supplementation in the form of cholecalciferol during pregnancy had a significant reduction on the risk of PTB. A systematic review found that oral supplementation with combination of cholecalciferol and calcium carbonate may increase the risk of PTB. The different dosages, frequencies, and time of initiation limit the generalizations for efficacy and safety doses. Due to limited data for maternal adverse events, no conclusions can be drawn. Research on the effect of oral vitamin D supplementation during pregnancy on the risk of PTB is still limited and need for more studies. Recommendation for vitamin D consumption based on the RDA needs to be fulfilled in pregnant women for the continuity of fetal growth and development.

Table 1. Resources and search strategy

\begin{tabular}{|c|c|c|c|}
\hline Database & Search strategy & Hits & $\begin{array}{c}\text { Selected } \\
\text { Article }\end{array}$ \\
\hline PubMed & $\begin{array}{l}\text { ((((("pregnancy"[Title/Abstract] AND ("vitamin D"[Title/Abstract] OR } \\
\text { "vitamin D supplementation"[Title/Abstract])) AND (("preterm } \\
\text { birth"[Title/Abstract] OR "preterm labor"[Title/Abstract]) OR } \\
\text { "premature birth"[Title/Abstract])) AND 2015/5/15:3000/1/1[Date - } \\
\text { Publication]]) AND ("systematic"[Filter] AND 2015/5/15:3000/1/1[Date } \\
\text { - Publication])) AND (("meta-analysis"[Publication Type] OR } \\
\text { "systematic"[Filter]) AND 2015/5/15:3000/1/1[Date - Publication])) } \\
\text { AND ((("clinical trial"[Publication Type] OR "meta- } \\
\text { analysis"[Publication Type]) OR "systematic"[Filter]) AND } \\
\text { 2015/5/15:3000/1/1[Date - Publication]) }\end{array}$ & 16 & 1 \\
\hline Cohrane & $\begin{array}{l}\text { ID Search } \\
\text { \#1 "pregnancy" } \\
\text { \#2 "vitamin D" OR "vitamin D supplementation" OR } \\
\text { "cholecalciferol' OR "ergocalciferol' } \\
\text { \#3 "preterm birth" OR "preterm labor" OR "premature birth" } \\
\text { \#4 \#1 AND \#2 AND \#3 with Cochrane Library publication date } \\
\text { Between May 2015 and May 2020, in Cochrane Reviews, Trials }\end{array}$ & 65 & 1 \\
\hline Wiley & $\begin{array}{l}\text { search result for [[All: "vitamin d"] OR [All: "vitamin d } \\
\text { supplementation"] OR [All: "cholecalciferol' or "]] AND [All: } \\
\text { ergocalciferol'] AND [[All: "preterm birth"] OR [All: "preterm labor"] } \\
\text { OR [All: "premature birth"]] AND [Earliest: (05/01/2015 TO } \\
\text { 05/31/2020)] }\end{array}$ & 23 & 1 \\
\hline
\end{tabular}


“pregnancy" AND "vitamin D OR vitamin D supplementation OR cholecalciferol OR ergocalciferol" AND "preterm birth OR preterm labor OR premature birth"

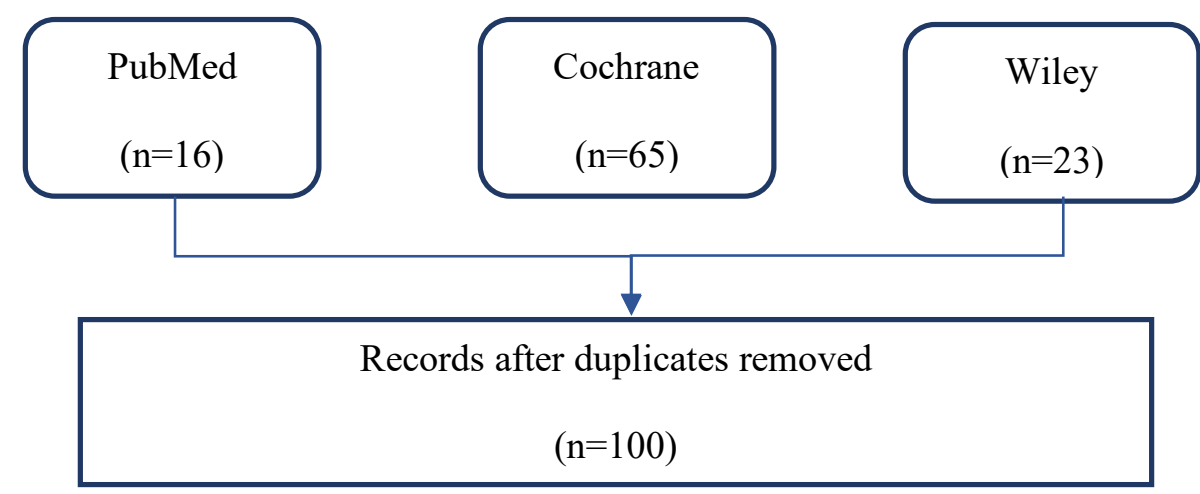

Inclusion criteria

- Pregnant women

- Oral vitamin D

supplementation

- Comparison with placebo or

without vitamin D

supplementation

- Preterm birth or preterm

labor as the study outcome

- Systematic review of RCT,

Meta-analysis, or RCT

- Publication within the last 5 years

Search date: May 15th, 2020
- Excluded because of the different at :

- Population $(\mathrm{n}=11)$

- Intervention or control $(\mathrm{n}=44)$

- Outcome $(\mathrm{n}=17)$

- Study design $(\mathrm{n}=19)$

- Non-English articles $(\mathrm{n}=0)$

- Full text not available $(\mathrm{n}=6)$
Studies

included

$(n=3)$

Figure 1. PRISMA flow chart 
Table 2. Characteristics of study

\begin{tabular}{|c|c|c|c|c|c|c|}
\hline$\frac{3}{2}$ & 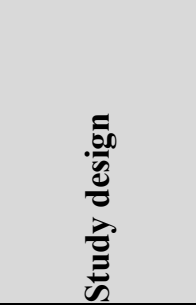 & 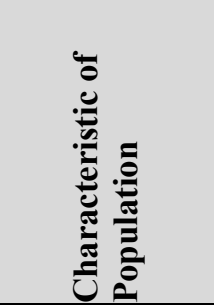 & 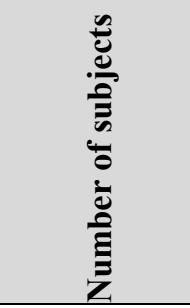 & 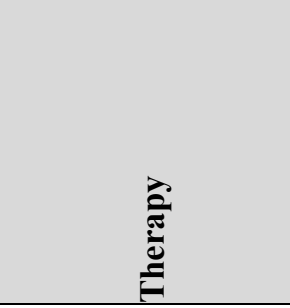 & 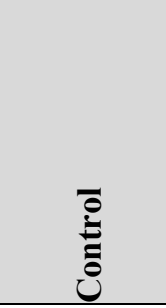 & 巳્ٍ \\
\hline $\begin{array}{l}\text { Sablok } \\
\text { A., et } \\
\text { al }^{11} \\
(2015)\end{array}$ & $\begin{array}{l}\text { Randomized } \\
\text { controlled } \\
\text { trials }\end{array}$ & $\begin{array}{l}\text { Primigravidae } \\
\text { with } \\
\text { singleton } \\
\text { pregnancy at } \\
14-20 \text { week }\end{array}$ & $\begin{array}{c}180 \\
\text { participants }\end{array}$ & $\begin{array}{l}\text { Group B (n=120), } \\
\text { classified as: } \\
\text { - } \text { Sufficient levels } \\
\text { of VD ( }> \\
\text { 50nmol/L) } \\
\text { received one } \\
\text { dose of } 60000 \\
\text { IU } \\
\text { cholecalciferol at } \\
20 \text { weeks } \\
\text { - Insufficient } \\
\text { levels }(25- \\
\text { 50nmol/L) } \\
\text { received two } \\
\text { doses of } 120000 \\
\text { IU at } 20 \text { and } 24 \\
\text { weeks } \\
\text { Deficient levels } \\
\text { (<25nmol/L) } \\
\text { received four } \\
\text { doses of } 120000 \\
\text { IU at } 20,24,28 \\
\text { and } 32 \text { weeks. }\end{array}$ & $\begin{array}{l}\text { Group A } \\
(n=60): \\
\text { NI }\end{array}$ & $\begin{array}{l}\text { - } \text { Risk of maternal } \\
\text { complications: PTL, } \\
\text { pre-eclampsia and } \\
\text { GDM associated with } \\
\text { VD deficiency } \\
\text { - Infants of mothers with } \\
\text { VD deficiency:_LBW } \\
\text { and Apgar score }\end{array}$ \\
\hline $\begin{array}{l}\text { Luz } \\
\text { Maria } \\
\text { D., et } \\
\text { al. }{ }^{14} \\
(2016)\end{array}$ & $\begin{array}{l}\text { Systematic } \\
\text { review }\end{array}$ & $\begin{array}{l}\text { Pregnant } \\
\text { women } \\
\text { without pre- } \\
\text { existing } \\
\text { condition, at } \\
\text { any } \\
\text { gestational or } \\
\text { chronological } \\
\text { age, parity } \\
\text { and number } \\
\text { of fetuses }\end{array}$ & $\begin{array}{c}15 \mathrm{RCT} \\
(2833 \\
\text { participants })\end{array}$ & $\begin{array}{l}\text { - VD } \\
\text { - VD + Ca } \\
\text { - VD + Ca + VM } \\
\text { VD varied in } \\
\text { dosage, regimen } \\
\text { and time to start. } \\
\text { VD form: } \\
\text { cholecalciferol-D3 } \\
\text { (10 trials), } \\
\text { ergocalciferol-D2 } \\
\text { (3 trials), and no } \\
\text { report (2 trials). } \\
\text { VD daily dose: } \\
200 \text { IU - 2000 IU } \\
\text { (to be continued in } \\
\text { the next page) }\end{array}$ & $\begin{array}{l}\text { - Placebo } \\
\text { or NI } \\
\text { - Ca } \\
\text { - Ca }+ \\
\text { VM } \\
\text { - VM }\end{array}$ & $\begin{array}{l}\text { - Primary outcomes: } \\
\text { Pre-eclampsia, GDM, } \\
\text { VD concentration at } \\
\text { term, adverse effects } \\
\text { (hypercalcaemia, } \\
\text { kidney stones), PTB } \\
\text { ( }<37 \text { weeks' gestation), } \\
\text { LBW (<2500 g). } \\
\text { - Secondary outcomes: } \\
\text { Impaired glucose } \\
\text { tolerance, caesarean } \\
\text { section, GH, maternal } \\
\text { death, birth length, } \\
\text { head circumference, } \\
\text { birth weight, admission } \\
\text { to special care during } \\
\text { the neonatal period, } \\
\text { stillbirth, neonatal } \\
\text { death, Apgar score, } \\
\text { neonatal infection, very } \\
\text { PTB (< 32 weeks' } \\
\text { gestation) }\end{array}$ \\
\hline
\end{tabular}


Table 2. Characteristics of study (continued)

\begin{tabular}{|c|c|c|c|c|c|c|}
\hline$\frac{2}{3}$ & 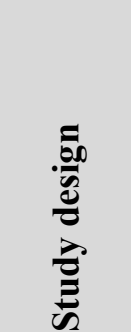 & 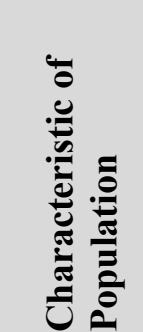 & $\begin{array}{l}\frac{n}{0} \\
\frac{d}{0} \\
\vdots \\
0 \\
0 \\
0 \\
\vdots \\
\vdots \\
\vdots \\
\vdots \\
\vdots \\
\mathbf{Z}\end{array}$ & हैं & 它 & 苞 \\
\hline $\begin{array}{l}\text { Luz Maria } \\
\text { D., et al. }{ }^{14} \\
\text { (2016) } \\
\text { (continued } \\
\text { from } \\
\text { previous } \\
\text { page) }\end{array}$ & & & & $\begin{array}{l}\text { (continued) } \\
\text { VD single-dose: } \\
200,000 \text { IU, 600,000 } \\
\text { IU, 35,000 IU per } \\
\text { week and dose } \\
\text { depended upon the } \\
\text { level of serum 25- } \\
\text { OHD levels at } \\
\text { baseline } \\
\text { VD time to start: } \geq \\
20 \text { weeks of } \\
\text { pregnancy } \\
\text { Ca supplementation: } \\
\text { Ca carbonate, doses } \\
\text { ranged from } 375 \text { mg } \\
\text { - } 1250 \text { mg } \\
\text { VM } \\
\text { supplementation: } \\
\text { Iron (60 mg ferrous } \\
\text { sulphate) } \\
\text { and folic acid ( } 400 \\
\text { mcg) }\end{array}$ & & \\
\hline $\begin{array}{l}\text { Zhou S., } \\
\text { et al }^{15} \\
(2017)\end{array}$ & $\begin{array}{l}\text { Meta- } \\
\text { analysis }\end{array}$ & $\begin{array}{l}\text { Pregnant } \\
\text { women } \\
\text { without } \\
\text { HIV } \\
\text { infection }\end{array}$ & $\begin{array}{l}6 \text { RCT (1687 } \\
\text { participants) } \\
\text { and } 18 \\
\text { observational } \\
\text { studies }\end{array}$ & $\begin{array}{l}\text { VD3 dosage ranged } \\
\text { from } 400 \text { IU daily to } \\
\text { multiple bolus } \\
\text { dosage of } 120,000 \\
\text { IU }\end{array}$ & $\begin{array}{l}\text { Placebo or } \\
\text { routine care } \\
\text { (ferrous } \\
\text { sulfate } 200 \\
\text { mg and Ca } \\
600 \mathrm{mg} \\
\text { daily, but no } \\
\text { VD) }\end{array}$ & $\begin{array}{l}\text { - Association between } \\
\text { maternal circulating 25- } \\
\text { OHD and the risk of } \\
\text { PTB or sPTB } \\
\text { - Effect of VD } \\
\text { supplementation during } \\
\text { pregnancy on reduce the } \\
\text { risk of PTB }\end{array}$ \\
\hline
\end{tabular}

RCT = Randomized Controlled Trial; IU = International Unit; 25-OHD = 25 hydroxyvitamin D; GDM = Gestational Diabetes; LBW = Low Birth Weight; PTB = Preterm Birth; sPTB = Spontaneous Preterm Birth; PTL = Preterm Labor; $\mathrm{GH}=$ Gestational Hypertension; VD = Vitamin D; VD3 = Vitamin D3; Ca = Calcium; VM = Vitamin and Mineral; NI = No Intervention. 
Table 3. Critical appraisal of the RCT study

\begin{tabular}{|c|c|c|}
\hline Parameters & Question & $\begin{array}{l}\text { Sablok A., et al. }{ }^{11} \\
(2015)\end{array}$ \\
\hline \multirow[t]{6}{*}{ VALIDITY } & Was the assignment of patient to treatments randomized? & Yes \\
\hline & Were the groups similar at the start of the trial? & Not Clear \\
\hline & $\begin{array}{l}\text { Aside from the allocated treatment, were groups treated } \\
\text { equally? }\end{array}$ & No \\
\hline & Were all patients who entered the trial accounted for? & No \\
\hline & $\begin{array}{l}\text { And were they analyzed in the group to which they were } \\
\text { randomized? }\end{array}$ & Yes \\
\hline & $\begin{array}{l}\text { Were measures objective or were the patients and } \\
\text { clinicians kept "blind" to which treatment was being } \\
\text { received? }\end{array}$ & Not clear \\
\hline \multirow[t]{2}{*}{ IMPORTANCE } & How large was the treatment effect? & $\mathrm{p}=0.02$ \\
\hline & How precise was the estimate of the treatment effect? & $\begin{array}{l}\text { Precise, the } 95 \% \mathrm{CI} \text { of the } \\
\text { results are narrow }\end{array}$ \\
\hline \multirow[t]{3}{*}{ APPLICABILITY } & $\begin{array}{l}\text { Is my patient so different to those in the study that the } \\
\text { results cannot apply? }\end{array}$ & No \\
\hline & Is the treatment feasible in my setting? & Yes \\
\hline & $\begin{array}{l}\text { Will the potential benefit of treatment outweigh the } \\
\text { potential harms of treatment for my patient? }\end{array}$ & Yes \\
\hline
\end{tabular}

Table 4. Critical appraisal of systematic review and meta-analysis

\begin{tabular}{|c|c|c|c|}
\hline Parameters & Question & $\begin{array}{l}\text { Luz Maria D., et al. }{ }^{14} \\
(2016)\end{array}$ & $\begin{array}{l}\text { Zhou S., et } \\
\text { al. }^{15} \\
(2017)\end{array}$ \\
\hline \multirow[t]{7}{*}{ VALIDITY } & $\begin{array}{l}\text { Did the meta-analysis address a focused } \\
\text { question (PICO)? }\end{array}$ & Yes & Yes \\
\hline & $\begin{array}{l}\text { Does the meta-analysis use it to direct the } \\
\text { search and select articles for inclusion? }\end{array}$ & Yes & Yes \\
\hline & Did the search find all the relevant evidence? & Yes & Yes \\
\hline & Have the studies been critically appraised? & Yes & Yes \\
\hline & Did they only include high quality studies? & No & No \\
\hline & $\begin{array}{l}\text { Have the results been totalled up with } \\
\text { appropriate summary tables and plots? }\end{array}$ & Yes & Yes \\
\hline & $\begin{array}{l}\text { And heterogeneity between studies assessed } \\
\text { and explained? }\end{array}$ & Yes & Yes \\
\hline \multirow[t]{3}{*}{ IMPORTANCE } & $\begin{array}{l}\text { Was measure clearly explained? } \\
\text { How are the results presented? }\end{array}$ & Yes & Yes \\
\hline & & Presented in Figure & Presented in \\
\hline & & Analysis $1-2$ & $\begin{array}{l}\text { Figure 1-4, } \\
\text { Supplementary } \\
\text { Figure 1-7 and } \\
\text { Summary of } \\
\text { findings }\end{array}$ \\
\hline APPLICABILITY & $\begin{array}{l}\text { Can we apply this valid, important evidence } \\
\text { about to our patients? }\end{array}$ & Yes & Yes \\
\hline
\end{tabular}




\section{Conflict of Interest}

Authors declared no conflict of interest regarding this study.

\section{Open Access}

This article is distributed under the terms of the Creative Commons Attribution 4.0 International Licence

(http://creativecommons.org/licenses/by/4.0/), which permits unrestricted use, distribution, and reproduction in any medium, provided you give appropriate credit to the original author(s) and the source, provide a link to the Creative Commons license, and indicate if changes were made.

\section{Reference}

1. World Health Organization. New global estimates on preterm birth published. Geneva; 2018.

2. Kim J. Preterm Labor and Birth: Definition, Assessment, and Management. Korean J Women Heal Nurs. 2018;24(3):231-2.

3. Taha Z, Hassan AA, Wikkeling-scott L, Papandreou D. Factors Associated with Preterm Birth and Low Birth Weight in Abu Dhabi, the United Arab Emirates. Int J Environ Res Public Heal. 2020;

4. UNICEF, WHO, World Bank Group, United Nations. Child Mortality Report 2018. 2018.

5. Cappelletti M, Bella S Della, Ferrazzi E, Mavilio $\mathrm{D}$, Divanovic S. Inflammation and preterm birth. JLB. 2016;99.

6. Qin L, Lu F, Yang S, Xu H, Luo B. Does Maternal Vitamin D Deficiency Increase the Risk of Preterm Birth: A Meta-Analysis of Observational Studies. Nutrients. 2016;

7. Varner MW, Wapner RJ, Jr JMT. Adverse Maternal and Neonatal Outcomes in Indicated Compared with Spontaneous Preterm Birth in Healthy Nulliparas; a secondary analysis of a randomized trial. Am J Perinatol. 2019;35(7):62431.

8. Samuel TM, Sakwinska O, Makinen K, Burdge GC, Godfrey KM, Silva-zolezzi I. Preterm Birth : A Narrative Review of the Current Evidence on Nutritional and Bioactive Solutions for Risk Reduction. Nutrients. 2019;1-26.

9. Selvaraj P. Vitamin D, Vitamin D Receptor, and Cathelicidin in the Treatment of Tuberculosis. 1st ed. Vol. 86, Vitamins and Hormones. Elsevier Inc.; 2011. 307-325 p.
10. Woo J, Giurgescu C, Wagner C. Evidence of an Association Between Vitamin D Deficiency and Preterm Birth and Preeclampsia: A Critical Review. jmwh. 2019;3:1-17.

11. Sablok A, Batra A, Thariani K, Batra A, Bharti A, Aggarwal A, et al. Supplementation of Vitamin D in pregnancy and its correlation with feto-maternal outcome. 2015;

12. Mojibian M, Soheilykhah S, Moghadam J. The effects of vitamin D supplementation on maternal and neonatal outcome: A randomized clinical trial. Iran J Reprod Med. 2015;13(11):687-96.

13. Persad MD, Staszewski CL, Khan F, Garry D, Herrera K, Garretto DJ. Does antepartum vitamin D3 supplementation prevent preterm birth? Am J Obstet Gynecol. 2019;220(1):S374-5.

14. Luz Maria D, Palacios C, Lk L, Jp P. Vitamin D supplementation for women during pregnancy ( Review ). Cochrane Database Syst Rev. 2016;(1).

15. Zhou S, Tao Y, Huang K, Zhu B, Tao F. Vitamin D and risk of preterm birth : Up-to-date meta-analysis of randomized controlled trials and observational studies. J Obs Gynaecol. 2017;43(2):247-56 